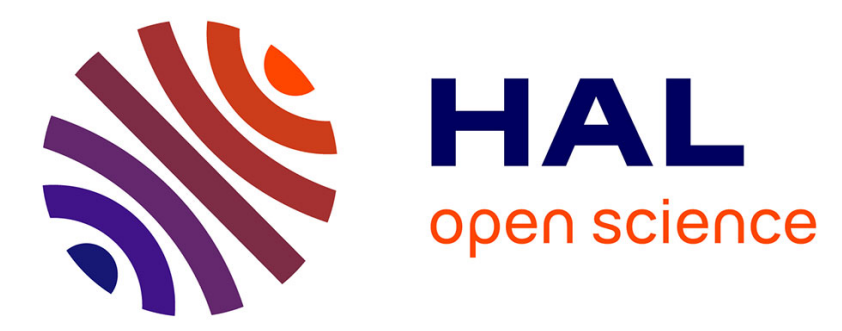

\title{
Post mortem development of meat quality as related to changes in cytoskeletal proteins of chickens muscles
}

Jolanta Tomaszewska-Gras, Jacek Kijowski

\section{To cite this version:}

Jolanta Tomaszewska-Gras, Jacek Kijowski. Post mortem development of meat quality as related to changes in cytoskeletal proteins of chickens muscles. British Poultry Science, 2011, 52 (02), pp.189-201. 10.1080/00071668.2011.561281 . hal-00686677

\section{HAL Id: hal-00686677 \\ https://hal.science/hal-00686677}

Submitted on 11 Apr 2012

HAL is a multi-disciplinary open access archive for the deposit and dissemination of scientific research documents, whether they are published or not. The documents may come from teaching and research institutions in France or abroad, or from public or private research centers.
L'archive ouverte pluridisciplinaire HAL, est destinée au dépôt et à la diffusion de documents scientifiques de niveau recherche, publiés ou non, émanant des établissements d'enseignement et de recherche français ou étrangers, des laboratoires publics ou privés. 


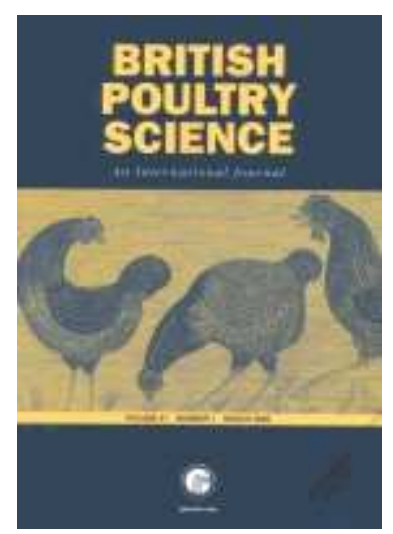

\section{Post mortem development of meat quality as related to changes in cytoskeletal proteins of chickens muscles}

\begin{tabular}{|r|l|}
\hline Journal: & British Poultry Science \\
\hline Manuscript ID: & CBPS-2009-280.R1 \\
\hline Manuscript Type: & Original Manuscript \\
\hline Aute Submitted by the \\
Author: & 02-Jun-2010 \\
\hline & $\begin{array}{l}\text { Tomaszewska-Gras, Jolanta; Poznan University of Life Sciences, } \\
\text { } \begin{array}{l}\text { Kijowski, Jacek; Poznan University of Life Sciences, Department of } \\
\text { Food Quality Management }\end{array}\end{array}$ \\
\hline Keywords: & $\begin{array}{l}\text { Biochemistry, Broilers, Meat, chicken meat ageing , SDS-PAGE \& } \\
\text { Western blotting, cytoskeletal proteins }\end{array}$ \\
\hline \multicolumn{2}{|l}{} \\
\hline
\end{tabular}

\section{SCHOLARONE \\ Manuscripts}


2 Post mortem development of meat quality as related to changes in cytoskeletal proteins

3 of chicken muscles

4 J. TOMASZEWSKA-GRAS, F. J.G. SCHREURS ${ }^{1}$ AND J. KIJOWSKI

$5 \quad$ Faculty of Food Science and Nutrition, Poznan University of Life Sciences, Wojska Polskiego

6 31, 60-624 Poznan, Poland, 'Institute for Animal Science and Health (ID-DLO), Lelystad,

7 The Netherlands

8

9

10

11

12

13

14

15

16

17

18

19

20

21

22 Correspondence to: Dr J. Tomaszewska-Gras, Faculty of Food Science and Nutrition,

23 Poznan University of Life Sciences, Wojska Polskiego 31, 60-624 Poznan, Poland.

24 E-mail: gras@up.poznan.pl
Running title: Meat quality and cytoskeletal proteins

Accepted for publication 13th October 2010 
26 Abstract 1. A procedure was developed to separate high and medium molecular weight myofibrillar proteins from chicken muscular tissue with a high resolution by flat bed sodiumdodecyl-sulphate polyacrylamide gel electrophoresis (SDS-PAGE) and subsequent detection by either a general protein stain or Western blotting. These procedures were used to analyse the degradation process of cytoskeletal proteins in chicken breast and leg muscles during meat ageing.

2. This study demonstrates the degradation of all the examined cytoskeletal proteins: titin, nebulin and desmin as well as vinculin, a protein composing the costamere structure. All the examined proteins were found to be degraded during ageing of chicken breast and leg muscles.

3. Degradation of titin, nebulin and desmin started at $3 \mathrm{~h}$ post mortem in breast muscle. Intact titin and nebulin disappeared within $1 \mathrm{~d}$. Intact desmin and vinculin were not detectable after $3 \mathrm{~d}$ post mortem. In leg muscle, the degradation process of all the examined proteins evolved much more slowly than in breast chicken muscles.

4. The changes observed in shear force, myofibrillar fragmentation and cooking loss were related to changes in cytoskeletal proteins and used to identify marker proteins or degradation products for the purpose of monitoring the development of meat ageing. The ageing process was faster in breast muscle than in leg muscle.

5. Significant correlations were found between degradation processes of titin, nebulin, and desmin and shear force, as well as myofibril fragmentation index of breast and leg muscles.

\section{INTRODUCTION}

The development of meat quality during ageing is dependent on the post mortem loss of longitudinal and lateral integrity of the muscular tissue, as a result of proteolytic degradation of cytoskeletal proteins resulting in tenderisation of meat (Young et al., 1980; Quali, 1992). During post mortem ageing of meat, the major contractile proteins of muscle, i.e. actin and 
51 myosin, together comprising approximately $80 \%$ of the myofibrillar mass, seem not to be 52 affected by proteolysis (Samejima and Wolfe, 1976; Yates et al., 1983; Bandman and Zdanis, 1988). The most important structural components involved in meat ageing are considered to be the cytoskeletal proteins, such as titin, nebulin and desmin (Koohmaraie et al., 1984; Fritz and Greaser, 1991; Robson, 1995) and vinculin (Taylor et al., 1995). Titin, also called connectin, is an extremely large monomerous protein found in striated muscle (Maruyama et al., 1977; Wang et al., 1979) which forms a set of longitudinal filaments spanning from the M-line region to the Z-line. Nebulin is considered to be a long molecule of molecular weight of approx. $800 \mathrm{kDa}$ which runs parallel to, and in close association with, the thin filaments. Both titin and nebulin are largely responsible for the longitudinal integrity of the muscular fibre. Desmin is a protein of approximately $53 \mathrm{kDa}$, present in intermediate filaments connecting adjacent myofibrils at their Z-line levels (Robson, 1995) and one of the many proteins composing the cell membrane skeleton, named costameres (Taylor et al., 1995). Desmin is considered to be the most important protein responsible for the lateral integrity of the muscle fibre (Robson, 1995). Vinculin is one of the most important proteins composing the costamere structure with a molecular weight of approx. $126 \mathrm{kDa}$ and belongs to a chain of proteins involved in forces of the myofibrils to the anchorites of the muscle (Taylor et al., 1995).

The kinetics of post mortem proteolytic degradation of these key cytoskeletal proteins is

70 of crucial importance for meat quality development. In the 1980s, most of the SDS-PAGE 71 studies were focused on the extremely large proteins, titin and nebulin, and their breakdown 72 (Lusby et al., 1983; Paterson and Parrish, 1987). Depending on the molecular weight of 73 myofibrillar proteins, different percentages of total acrylamide and crosslinker have been used 74 throughout literature to produce gels of various porosities and with good separating 75 capabilities. For the extremely large myofibrillar proteins, such as titin and nebulin, with 
76 molecular weights of approximately 2800 and $800 \mathrm{kDa}$, respectively, highly porous 77 polyacrylamide gels have been utilised. These gels are extremely difficult to handle, 78 especially during Western blotting or staining, due to their fragile nature. The gels described 79 in literature for the separation of these high molecular weight proteins, without exception, 80 were of the 'vertical slab-gel type' (Studier, 1973; Porzio and Pearson, 1977; Paterson and 81 Parrish, 1987; Fritz et al., 1989; Granzier and Wang, 1993).

82 Because of the limited sensitivity and separation of proteins by SDS-PAGE, it was 83 necessary to search for a new, more sensitive technique to detect proteins and their 84 degradation products, which are present in the muscle at very low concentrations. 85 Cytoskeletal proteins and some of their degradation products separated on these gels may be 86 detected very sensitively and specifically by Western blotting, first introduced by Burnette 87 (1981), however, chicken myofibrillar proteins are very difficult to separate (Chou et al., 88 1994). Bandman and Zdanis (1988) successfully used Western blotting to study protein 89 breakdown in beef with antibodies to myosin and titin. This immunochemical method has also 90 been used in studies on titin and nebulin breakdown in bovine meat by Fritz and Greaser 91 (1991) and in studies on the breakdown of desmin in chicken muscle by Schreurs (1991). 92 Taylor et al. (1995) used Western blotting and electron microscopy to demonstrate that the 93 first change occurring in post mortem beef muscle was the disintegration of the N2-line and 94 costameres.

95 Presently, little is known about the changes in cytoskeletal proteins of poultry meat, and 96 so the purpose of this study was to investigate the degradation of cytoskeletal proteins in 97 chicken muscle during post mortem ageing. Sample preparation, gel casting and Western 98 blotting were optimised for chicken muscle tissue. The utilised gels were ultra-thin, highly 99 porous polyacrylamide gels on a plastic backing film, and were used in a flat-bed gel100 electrophoresis set-up. This procedure resulted in very high-resolution electropherograms for 
101 high molecular weight proteins. The procedure was adapted to medium molecular weight 102 myofibrillar proteins, such as vinculin and desmin, using precast, commercially available 103 SDS-PAGE gels of 7.5 and $12.5 \%$ total acrylamide, resulting in a comparably high 104 resolution.

105 In order to be able to relate changes observed in the cytoskeletal proteins to meat quality 106 characteristics, myofibrillar fragmentation as well as cooking loss and shear force were 107 measured in both breast and leg muscles.

\section{MATERIALS AND METHODS}

109 Water was always of Milli-Q (Millipore, The Netherlands) quality. Standard laboratory 110 chemicals were obtained from Merck and were of analytical grade, unless stated otherwise. 111 Precast ExcelGel SDS Homogeneous 7.5\% (no. 80-1260-01) and gradient 8-18\% gels, 112 ExcelGel SDS buffer strips (no. 17-1342-01) and Coomassie brilliant blue were obtained 113 from Pharmacia. Acrylamide/bisacrylamide and tetraethylenemethylene-diamine (TEMED) 114 were obtained from BDH. Reinforced nitro-cellulose membranes, pore size $0.45 \mu \mathrm{m}$, for 115 Western blotting were obtained from Schleicher and Schuell.

116 Animals and sampling techniques

117 A total of 210 6-week-old Ross commercial broilers were obtained on two occasions from a 118 local slaughterhouse, transported to the Institute in typical commercial broiler crates, and 119 subsequently slaughtered at the in-house processing plant of the Institute for Animal Science 120 and Health (ID-DLO, Lelystad). Birds were stunned in a water bath stunner set at $100 \mathrm{~V}$ and $12150 \mathrm{~Hz}$ for approximately $10 \mathrm{~s}$, and the jugular veins severed with a rotating knife, but were 122 not scalded, plucked or eviscerated. After an approximate 3-min bleeding time, birds were 123 skinned and deboned. The initial $(0 \mathrm{~h})$ samples for electrophoresis were taken immediately 124 after excision of the muscles, frozen in liquid nitrogen, and stored at $-80^{\circ} \mathrm{C}$. Subsequently, 125 skinned breast and leg parts were wrapped in paper towels saturated with an antimicrobial 
126 solution (10 mM sodium azide, $100 \mathrm{mg} / \mathrm{kg}$ chloramphenicol, $10 \mathrm{mg} / \mathrm{kg}$ riframycin) and kept

127 in a cold room at $4^{\circ} \mathrm{C}$ for sampling at 1,3 and $6 \mathrm{~h}$ and further at $1,2,3,5$, and $7 \mathrm{~d}$ of post 128 mortem storage. Samples for SDS-PAGE and Western blotting, as well as for the 129 measurement of the myofibrillar fragmentation index (MFI), were taken repeatedly from the 130 same 9 carcases at the above mentioned times post mortem.

131 The cooking loss and shear force measurements were carried out at 8 sample times on

13212 different carcases per sampling time (96 animals in total). The experiment described above 133 was repeated two times, which resulted in 210 animals being used in all the measurements: 18 134 carcases (9 carcases x 2 experiments) for SDS- PAGE, Western blotting and MFI, and 192 135 carcases (12 carcases $\mathrm{x} 8$ periods $\mathrm{x} 2$ experiments) for shear force, $\mathrm{pH}$ and cooking loss.

\section{Sample preparation}

137 Whole muscle samples (breast, pectoralis major, and thigh muscle, biceps femoris) for SDS138 PAGE and Western Blotting were taken (approximately $2 \mathrm{~g}$ ) at the above times post mortem, 139 frozen in liquid nitrogen and stored at $-80^{\circ} \mathrm{C}$ until analysis. On the day of analysis, samples 140 were again cooled in liquid nitrogen and subsequently pulverised using a liquid nitrogen 141 cooled mortar and pestle. The resulting powder was dissolved into a volume of sample buffer 142 according to Fritz and Greaser (1991), containing $25 \mathrm{mM}$ Tris- $\mathrm{HCl} \mathrm{pH}=6.8,8 \mathrm{M}$ urea, $2 \mathrm{M}$ 143 thiourea, 3\% (w/v) SDS, $75 \mathrm{mM}$ dithiothreitol (DTT) and bromophenol blue, to yield a 144 protein concentration of $1 \mathrm{mg} / \mathrm{ml}$. Samples were heated for $20 \mathrm{~min}$ at $50^{\circ} \mathrm{C}$ and subsequently 145 cooled in tap water to room temperature and centrifuged at $12000 \mathrm{~g}$ for $5 \mathrm{~min}$.

\section{Polyacrylamide gel preparation}

147 Commercially available precast ExcelGels $(12.5 \times 260 \times 0.5 \mathrm{~mm})$ with homogeneous $7.5 \%$ 148 and a gradient of 8 to $18 \%$ total acrylamide were used. For the separation of high molecular 149 weight proteins, such as titin and nebulin, special gels of $3.2 \%$ total acrylamide 150 (bisacrylamide:acrylamide, 1:37) were prepared; 3.2\% homogeneous polyacrylamide gels 
151 were cast in gel cassettes of $12.5 \times 260 \times 1.0 \mathrm{~mm}$ with sample wells of $5 \times 5 \times 1.0 \mathrm{~mm}(=25$

$152 \mu \mathrm{l})$, containing a GelBond PAG plastic backing film obtained from Pharmacia. The casting 153 solution was composed of $3.2 \%$ acrylamide, $0.08 \% \mathrm{~N}$, N'-methylene-bisacrylamide, 375

$154 \mathrm{mM}$ Tris.HCl $\mathrm{pH} 8.8,0.1 \%$ SDS, $0.03 \mathrm{mg} / \mathrm{ml}$ ammonium persulphate and 0.4\% TEMED.

155 After polymerisation and disassembly of the gel cassettes, the gel was covalently bound to the 156 plastic backing film and could be easily removed from the gel casting moulds and positioned 157 on top of the cooling plate of the Multiphor II electrophoresis unit.

\section{Electrophoresis}

159 Flat bed SDS-PAGE was performed with a horizontal Pharmacia LKB Multiphor II System. 160 Muscle samples were loaded on $7.5 \%$ and $12.5 \%$ gels $(10 \mu \mathrm{g}$ of protein) and on $3.2 \%$ gel (20 $161 \mu \mathrm{g}$ of protein). On the $7.5 \%$ and $12.5 \%$ gels, several aliquots of a mixture of Pharmacia low 162 molecular weight (LMW) and high molecular weight HMW-SDS (Pharmacia, 17-0615-01) 163 calibrators were applied to estimate the molecular weight of different bands. Onto gels used 164 for subsequent western blotting also a mixture of the above mentioned standards was applied 165 as well as samples prepared from muscle tissue that were frozen immediately after slaughter; 166 ExcelGel buffer strips $(245 \times 4.5 \mathrm{~mm})$ were used as anodic and cathodic buffers. The strip 167 buffer system formed, together with the gel buffer, a discontinuous buffer system. High- and 168 low-molecular weight standards from Pharmacia were used to identify protein molecular 169 weights. Electrophoresis was performed at the constant current of $50 \mathrm{~mA}$ with the power 170 supply set at a maximum of $600 \mathrm{~V}$ and a maximum power of $30 \mathrm{~W}$. The power supply was 171 equipped with a volt-hour ( $\mathrm{VH})$ integrator and electrophoresis was extended until $500 \mathrm{VH}$ per 172 gel had been recorded.

\section{Fixation and staining}

174 Immediately after electrophoresis, gels were immersed in a fixing solution (40\% ethanol, 10\% 175 acetic acid) for $30 \mathrm{~min}$. Subsequently, gels were incubated in the staining solution of $0.05 \%$ 
176 Coomassie brilliant blue R-250 (PhastGelBlueR, Pharmacia, no. 17-0518-01) in 25\% ethanol,

$1778 \%$ acetic acid for $30 \mathrm{~min}$, after which, gels were destained in the destaining solution (25\%

178 ethanol, 8\% acetic acid) until a clear background was obtained. Destained gels were soaked in

179 the preserving solution (10\% acetic acid, $10 \%$ glycerol), and then dried covered with a clear

180 cellophane preserving film.

\section{Western blotting and detection}

182 Immediately after electrophoresis, as described above, gels were separated from the backing

183 film and transferred to a nitro-cellulose membrane, soaked in transfer buffer (25 mM Tris-192

$184 \mathrm{mM}$ glycine, $\mathrm{pH}=8.3,0.1 \% \mathrm{w} / \mathrm{v}$ SDS and $10 \% \mathrm{v} / \mathrm{v}$ methanol). Subsequently, proteins were

185 transferred from the gel onto the nitro-cellulose membrane by a semi-dry transfer method 186 using a constant voltage setting of $500 \mathrm{~V}$ for $120 \mathrm{~min}$, and then blotted membranes were 187 incubated with blocking solution (Phosphate buffered saline (PBS) containing 0.1\% Tween18820 and $5 \%$ non-fat dry milk) for $30 \mathrm{~min}$ at $37^{\circ} \mathrm{C}$ to saturate protein binding places on nitro189 cellulose. Saturated membranes were later immersed in diluted primary antibody in 190 incubation buffer (PBS containing 0.1\% Tween-20 and 0.1\% non-fat dry milk) and incubated 191 overnight at $4^{\circ} \mathrm{C}$ in a moist environment. Antibodies and dilutions used were as follows:

192 Rabbit polyclonal antibody raised against titin at the Institute for Animal Science and Health 193 diluted 1:2500

194 Rabbit polyclonal antibody to desmin, Sigma D-8281, diluted 1:400

195 Mouse monoclonal antibody to nebulin, Sigma N-9891, diluted 1:400

196 Mouse monoclonal antibody to vinculin, Sigma V-9131, diluted 1:200.

197 After overnight incubation, membranes were washed 3 times with incubation buffer to 198 remove excess antibody. Subsequently, membranes were incubated with a secondary antibody 199 alkaline phosphatase conjugate, either anti-rabbit (Boehringer Mannheim No. 1214-632; 200 diluted 1:2 000) or anti-mouse (Sigma A-3688; diluted 1:1 000), for $3 \mathrm{~h}$ at room temperature. 
201 The detection of alkaline phosphatise, and thus antigen-antibody complexes, was carried out 202 for $5 \mathrm{~min}$ using a $0.45 \mathrm{mg} / \mathrm{ml}$ solution of 5-bromo-4chloro-3-indolyl phosphate/nitro blue 203 tetrazolium (Sigma No. B-5655) chromogenic substrate. The reaction was stopped by quickly 204 rinsing the membrane in water.

\section{Densitometry}

206 Gels and blots were scanned on a Hewlett Packard 6100C tabletop scanner with 400 dpi, 207 which is comparable to a resolution of $63.6 \mu \mathrm{m}$. Image scans were subsequently processed as 208 densitometer traces on a tabletop computer equipped with the Quantiscan programme from 209 Biosoft. From the analysis of lanes containing calibrator samples, a standard molecular weight 210 calibration curve was prepared. For the analysis of high molecular weight proteins, titin and 211 nebulin, a molecular weight calibration curve was prepared using bands appearing in the fresh 212 muscle sample lane. For this purpose, molecular weight of intact titin was set to $2800 \mathrm{kDa}$, 213 intact nebulin to $800 \mathrm{kDa}$, and myosin heavy chain to $212 \mathrm{kDa}$.

214 Titin and nebulin contents were calculated by conversion to the known quantity of the 215 internal standard ( $\beta$-galactosidase) introduced to the meat sample according to the method 216 published by Tomaszewska-Gras et al. (2002). A total of 18 gels were run (9 carcases x 2 217 experiments). For gel densitometry analysis, a total of 13 (best stained, undisturbed) gels were 218 selected for each carcase from the two experiments.

\section{Myofibrillar fragmentation index (MFI)}

220 Repeated MFI measurements were carried out according to Olson et al. (1976). In the MFI 221 method, absorbance was measured in a suspension of isolated myofibrils. This index defines 222 the degree of myofibril fragmentation to shorter fragments during meat ageing. This method 223 consists of the following stages: myofibril extraction, determination of myofibrillar protein 224 concentration and determination of the index. Samples (4 g) were weighed in two replications 225 from each cooled breast (P. major) and thigh muscles (three thigh muscles mixed together: $m$. 
226 quadriceps femoris, biceps femoris and m. semitendinosus), and $40 \mathrm{ml}$ MFI buffer chilled to $2272{ }^{\circ} \mathrm{C}$ were added to each sample. The composition of MFI buffer: $75 \mathrm{mM} \mathrm{KCl}, 10 \mathrm{mM}$ 228 K2HP04, 5 mM EDTA, 1 mM NaN3, 1 mM PMSF, 1mM 1,4-disulfanylbutane-2,3-diol, $\mathrm{pH}=$

229 7.0. Samples were homogenised at a high rotational speed for $30 \mathrm{~s}$ and next centrifuged (1000 $230 \mathrm{~g}$ for $15 \mathrm{~min}$ at $2^{\circ} \mathrm{C}$ ). In order to remove sarcoplasmic proteins, the supernatant was decanted 231 and the remaining myofibril precipitate $40 \mathrm{ml}$ MFI buffer added and myofibrils washed. After 232 myofibril precipitate was obtained, $20 \mathrm{ml}$ MFI buffer were added. The suspension was filtered 233 through fine sieves $(1 \mathrm{~mm}$ mesh size $)$ in order to remove connective tissue. In such prepared 234 myofibril suspension, protein concentration was determined by the biuret method. A total of $2350.25 \mathrm{ml}$ was collected from the myofibril suspension in two replications and $0.75 \mathrm{ml} \mathrm{MFI}$ 236 buffer was added, to which $4 \mathrm{ml}$ biuret reagent were added and the sample mixed. Samples 237 were placed in the dark for $30 \mathrm{~min}$. Simultaneous with sample analyses, a standard curve was 238 prepared from bovine albumin (BSA) at concentrations of 0, 2.5, 5.0, 7.5 and $10 \mathrm{mg} / \mathrm{ml}$. 239 Absorbance was read on a spectrophotometer at a wavelength of $540 \mathrm{~nm}$. Based on the 240 standard curve and the size of absorbance, the protein concentration was determined in each 241 sample. Samples at a protein concentration of $0.5 \mathrm{mg} / \mathrm{ml}$ were prepared in two replications for 242 MFI measurements. After samples were mixed, their absorbance was measured at a 243 wavelength of $540 \mathrm{~nm}$. The fragmentation index was calculated by multiplying the result by 244200.

245 pH measurement

246 Changes in hydrogen ion concentration were measured directly in breast and thigh muscles 247 using a stiletto electrode of a CG - $837 \mathrm{pH}$-meter by Schott.

\section{Cooking loss and shear force}

249 Breast halves and legs designated for shear force measurements were weighed, vacuum sealed 250 and heated to a core temperature of $85^{\circ} \mathrm{C}$ in a boiling water bath and, immediately after 
251 heating, brought back to $25^{\circ} \mathrm{C}$ in a water bath. Immediately before shear force measurement, 252 samples were removed from the sealing bag and blotted dry with a paper towel. Subsequently, 253 samples were re-weighed and weight differences before and after heating recorded as cooking 254 loss.

\section{Shear force measurements}

256 The cooked and chilled muscle samples were excised with a special scalpel, longitudinally to 257 the muscle fibres to reach sample dimensions: $1 \times 1 \times 5 \mathrm{~cm}$. Breast muscle (P. major) and 258 three thigh muscles (m. quadriceps femoris, biceps femoris, m. semitendinosus) were taken for 259 shear force analysis. Measurements of shear force were carried out on an Adamel Lhomargy 260 instrument (Division Instruments S.A., Paris, France) with a single-knife Warner-Bratzler 261 attachment. Shear force values were expressed in N/cm2.

\section{Statistical analysis}

263 All results obtained in the two experiments were statistically analysed and no effect of flock

264 found. Repeated measures ANOVA was carried out on the MFI data using the general linear 265 models module of the SPSS/Windows ${ }^{\circledR}$ statistical package. For cooking loss and shear force 266 measurements, a one-way ANOVA was used. Correlation coefficients of the relationships of 267 MFI, cooking loss and shear force with the optical density classification of the different 268 proteins bands on the Western blots was carried out with the Spearman rank correlation 269 module after the classification were converted to scores in the following manner: $-=0, \pm=1$, $270+=2,++=3,+++=4$. Significant differences were identified at $P<0.05$.

\section{RESULTS AND DISCUSSION}

\section{SDS-PAGE and Western blotting}

273 Results of SDS-PAGE and Western blotting analyses are shown in Figures 1, 2, 3 and 4. 274 Figure 1 shows results of SDS-PAGE for meat proteins on 3.2\% (self-made) and Figure 2 on $2757.5 \%$ (precast) total acrylamide gels. The lower gel concentration was used for the separation 
276 of proteins larger than $200 \mathrm{kDa}$ in size. Bands of titin and nebulin from $7.5 \%$ gels were 277 determined quantitatively (Table 1) according to the method published by Tomaszewska-Gras 278 et al. (2002). Figures 3 and 4 show results of Western blots from $7.5 \%$ total acrylamide gels 279 with electropherograms of meat proteins developed with polyclonal anti-titin and monoclonal 280 anti-nebulin antibodies respectively, and from $12.5 \%$ total acrylamide gels with polyclonal 281 anti-desmin and monoclonal anti-vinculin antibodies respectively. Western blotting analysis 282 was performed to examine degradation products of proteins and their molecular weight. Table 2832 shows results of semi-quantitative scoring of banding patterns that will be discussed below. 284 Titin degradation was analysed on the basis of SDS-PAGE with a 3.2\% gel (Figure 1), a $2857.5 \%$ gel (Figure 2) and Western blotting (Figure 3). The results from 3.2 SDS PAGE gel at 286 death showed that titin in breast and leg meat was visible as a closely-spaced doublet T1 and 287 T2; this is in agreement with other studies (Wang, 1982; Kimura et al., 1984). With 288 increasing time post mortem, the amount of titin T1 decreased and the amount of titin T2 289 increased in all analysed samples. In breast meat, this phenomenon was most noticeable $6 \mathrm{~h}$ 290 post mortem, when the $\mathrm{T} 2$ band was much more intensive than in the 0 -h sample. This 291 suggests that $\mathrm{T} 2$ was raised from the degradation of $\mathrm{T} 1$. The $\mathrm{T} 1$ to $\mathrm{T} 2$ conversion was 292 completed in all samples $24 \mathrm{~h}$ post mortem, when T1 was no longer detectable, whereas T2 293 remained present for 7 d. Leg muscle samples show a comparable conversion of T1 into T2. 294 Although the same amounts of protein were applied to gels in case of breast muscle samples, 295 leg muscle samples showed a larger number of smaller titin degradation products, appearing 296 as faint banding patterns between titin and nebulin, than was the case for breast muscle 297 samples. Tables $1 \& 2$ and Figures 1, 2, 3 \& 4 near here

298 The analysis of quantitative changes in titin and nebulin cytoskelatal proteins was 299 carried out by SDS-PAGE on $7.5 \%$ gel. For gel densitometry analysis, a total of 13 (best 300 stained, undisturbed) gels were selected for each carcase (breast and leg) from the two 
301 experiments. The losses of intact titin and nebulin were determined quantitatively using a 302 known quantity of the internal standard, which had been introduced to each sample of meat 303 (Tomaszewska-Gras et al., 1999, 2002). The analytical results are presented in Table 1. Titin 304 content decreased significantly in breast muscle after $1 \mathrm{~d}$, whereas it was after 2 and $3 \mathrm{~d}$ of 305 refrigerated storage in thigh muscles. The observation of titin bands on gel revealed that the 306 disappearance of the $\mathrm{T} 1$ form of titin, both in breast and thigh muscles, resulted in a 307 significant decrease of the titin quantity over the studied period. In case of nebulin, significant 308 differences in its content were noted in breast muscle after $24 \mathrm{~h}$ and in thigh muscles after 48 $309 \mathrm{~h}$ of storage. It was also observed on gels that a significant decrease of nebulin content was 310 associated with the total degradation of its native form of $800 \mathrm{kDa}$ to the form of $600 \mathrm{kDa}$.

311 The Western blotting analysis with polyclonal antibodies to titin was used to detect 312 degradation products of titin. On the titin blot of breast muscle (Figure 3), 5 clearly visible 313 titin degradation products were identified, referred to as $\mathrm{Ta}, \mathrm{Tb}, \mathrm{Tc}, \mathrm{Td}$ and $\mathrm{Te}$. Components 314 Ta, Tc, Td and Te with molecular weights of approx. 1700, 1100, 900 and $700 \mathrm{kDa}$ 315 respectively, already appeared early post mortem (at $3 \mathrm{~h}$ ) as very faint bands. The relative 316 amount of these components increased gradually until the second day post mortem, when the 317 highest concentration was recorded except for Tc, of which the largest relative amounts were 318 present during the first day after slaughter. The fifth component $\mathrm{Tb}$, with a molecular weight 319 of approx. $1400 \mathrm{kDa}$, appeared at $3 \mathrm{~d}$ post mortem just below titin T2. The $\mathrm{T} 1$ form was 320 already degraded at that time. A more complex pattern of titin degradation products appeared 321 in leg muscle, with some very distinct bands. At least 6 bands could be identified, designated $322 \mathrm{Ta}, \mathrm{Tb}, \mathrm{Tc}, \mathrm{Td}, \mathrm{Te}$ and Tf, with approximate molecular weights of 1900, 1400, 1100, 900, 700 323 and $500 \mathrm{kDa}$ respectively. The Ta, as well as the intact titin band, gradually decreased during 324 the measuring period. All the lower molecular weight bands $\mathrm{Tc}, \mathrm{Td}, \mathrm{Te}$, and $\mathrm{Tf}$ gradually 325 increased until an intensity plateau was reached after 72 h. No disappearance of degradation 
326 bands was observed within $7 \mathrm{~d}$ post mortem, with the exception of the Tc band. It was faintly

327 present from $0 \mathrm{~h}$ on and increasing in optical density during aging, but almost disappeared in

328 the 7-d sample. The Tb component appeared in the 24-h sample and remained as a faint band

329 up to $7 \mathrm{~d}$ post mortem. The presence of 1700 and $400 \mathrm{kDa}$ degradation bands in chicken

330 breast muscle had previously been reported (Kimura et al., 1984), the first probably

331 corresponding to the Ta band. Chou et al. (1994) identified a $1200 \mathrm{kDa}$ component in chicken

332 leg meat, but not in breast meat. In our study, corresponding $1100 \mathrm{kDa}$ bands were identified

333 in both muscle types. Tanabe et al. (1992) suggested that this component originates from T1

334 and is composed of the Z-line side part of the T1 molecule.

335 SDS-PAGE and Western blotting results prepared from $7.5 \%$ gels with monoclonal

336 antibodies to nebulin, as shown in Figure 4, demonstrated that the degradation process of

337 nebulin in breast muscle started after $3 \mathrm{~h}$ as a small, diffuse smearing in the nebulin band and

338 became more intense with the increasing storage time. The cleavage of nebulin into two bands

339 was observed $6 \mathrm{~h}$ after slaughter; intact nebulin with a molecular weight of approximately 800

$340 \mathrm{kDa}$ and an immunoreactive degradation product with a molecular weight of approximately

$341500 \mathrm{kDa}$, designed $\mathrm{Na}$. After $72 \mathrm{~h}$ of storage, a smaller degradation product, designed $\mathrm{Nb}$,

342 was found on blots with a molecular weight of approx. $400 \mathrm{kDa}$. After 5 and $7 \mathrm{~d}$ of storage,

343 these two bands remained visible. In leg muscle, after $6 \mathrm{~h}$ only a small fraction of the original

344 intact nebulin was left. After $24 \mathrm{~h}$ post mortem, most of the nebulin was degraded into a

345 smaller cleavage product, designed $\mathrm{Na}$, with a molecular weight of $500 \mathrm{kDa}$. Within $72 \mathrm{~h}$ post

346 mortem, virtually all nebulin was degraded into smaller, no longer immunoreactive,

347 fragments. Only small amounts of two fragments, the $\mathrm{Na}$ fragment and a new cleavage

348 product designed $\mathrm{Nb}$, with an apparent molecular weight of approximately $400 \mathrm{kDa}$, remained

349 visible. On some blots the latter proteolytic fragment appeared as a closely spaced doublet. 
350 Based on blots, it may be concluded that the breakdown of nebulin was most prominent 351 between 3 and $48 \mathrm{~h}$, when intact nebulin was degraded and disappeared. This fact is 352 consistent with previous reports, where the degradation of nebulin was analysed only by SDS353 PAGE (Paxhia and Parrish, 1988; Chou et al., 1994).

354 Figure 4 shows also the results of Western blotting with polyclonal antibodies to 355 desmin. The results showed that in breast muscle, desmin degradation process started within 3 $356 \mathrm{~h}$ storage. Below the native band $(53 \mathrm{kDa})$ of desmin, a faint band of approx. $47 \mathrm{kDa}$ 357 appeared, referred to as component Da. A new band was visible on the blot after $6 \mathrm{~h}$ ageing, 358 designated $\mathrm{Db}$, with a molecular weight of approx. $40 \mathrm{kDa}$. These two bands remained very 359 strong until the second day. The most remarkable degradation of desmin in breast muscle 360 occurred between 6 and $72 \mathrm{~h}$ post mortem. After this time, intact desmin disappeared 361 completely and only three bands of products, i.e. $\mathrm{Da}(47 \mathrm{kDa}), \mathrm{Db}(40 \mathrm{kDa})$ and $\mathrm{Db}(34 \mathrm{kDa})$, 362 remained until the seventh day of storage. In leg muscle, desmin degradation was much 363 slower, with only very faint degradation visible after $24 \mathrm{~h}$. At $48 \mathrm{~h}$, the density of the native 364 molecule started to become faint and clearly defined degradation products started to appear. 365 The degradation pathway seems to be equal to that of the breast muscle, although much 366 retarded. In other studies of desmin degradation by Western blotting analysis bovine meat was 367 used (Hwan and Bandman, 1989; Taylor et al., 1995). It has been established that the 368 degradation of desmin in the bovine semimembranosus muscle, a fast-ageing muscle type, 369 occurred between 24 and 72 h, while in bovine biceps femoris, a slow-ageing muscle type, 370 desmin degradation was much slower.

371 Degradation of vinculin was completed in breast muscle within $3 \mathrm{~d}$ post mortem, when 372 intact vinculin was invisible on Western blots (Figure 4). In studies on vinculin degradation, it 373 was difficult to establish the time when degradation started as a result of the use of a 374 monoclonal antibody. The antibody is too specific to be able to pick up degradation products. 
375 In leg muscle, vinculin degradation was much slower, as is shown by the intact molecule still 376 being present vaguely $7 \mathrm{~d}$ post mortem. A comparison of chicken muscle to the fast-ageing 377 bovine semimembranosus muscle (Taylor et al., 1995) showed that vinculin disappeared at 378 the same time.

379 In conclusion, it may be stated that on titin and desmin blots, the intact protein molecule 380 and immunoreactive degradation products were visible, progressing in time post mortem. 381 Monoclonal antibodies against nebulin also recognised some breakdown, as it was shown by 382 the decrease in intact protein. The degradation pathway of nebulin generates some 383 degradation products that are still recognised by the monoclonal antibody. The monoclonal 384 anti-vinculin antibody was not capable of detecting degradation products of the native protein. 385 This means that, in order to detect degradation products, the use of polyclonal antibodies is 386 still preferred. Desmin and vinculin bands are not made visible on gels by Coomassie 387 staining. Desmin constitutes about $0.18 \%$ of skeletal muscle protein (Pearson and Young, 388 1989). Vinculin has been calculated to comprise about $0.005 \%$ of breast muscle proteins 389 (Maruyama, 1985). Both these proteins are easily visualised on Western blots.

\section{Myofibrillar fragmentation index (MFI) during post mortem storage}

392 MFI is a measure of the average length of myofibrils and is significantly related to tenderness, 393 i.e. with shorter myofibrils the index and meat tenderness values are higher (Taylor et al., 394 1995). Most studies on MFI have related this index at a specified time post mortem and most 395 of them were conducted on beef. In this study we monitored changes in MFI in breast and leg 396 chicken muscles during $7 \mathrm{~d}$ of storage. Table 3 shows the results of MFI measurement with 397 the time post mortem. In breast muscle (P. major), MFI increases during post mortem ageing 398 until it reaches plateau values after $24 \mathrm{~h}$. In leg muscles (three muscles: biceps femoris, 399 quadriceps femoris, semitendinosus considered as a whole), MFI increases gradually during 
400 the whole post mortem period that was investigated. Values recorded in leg muscle are 401 approximately 0.5 the values observed in breast muscle. Differences in absolute MFI values 402 indicate a scatter trend of breast muscle myofibrils different from the scatter trend for leg 403 muscle myofibrils.

404 The highest increase of MFI value in breast muscle was recorded $24 \mathrm{~h}$ after slaughter 405 and reached approximately $100 \%$ of the initial value. In thigh muscles, MFI increased by 406 approx. $60 \%$ of the initial value after $48 \mathrm{~h}$ of storage. This indicates much slower and less 407 intensive myofibrillar degradation in leg than in breast muscles, which may be the effect of 408 smaller amounts of proteolytic enzymes in thigh muscles. These results are consistent with the 409 results of the SDS-PAGE and Western blotting experiments (Figures 1, 2, 3 and 4) and results 410 reported in literature. In beef, MFI increases much more quickly in predominantly white 411 muscles rather than in red muscles (Olson et al., 1976). Similar results were observed by 412 Taylor et al. (1995) on beef, where MFI index for the 'fast-aging' semimenbranosus muscle 413 was higher than for the 'slow aging' biceps femoris muscle. Ultramicroscopic changes related 414 to post mortem proteolytic degradation proceed much more quickly in chicken breast muscle 415 than in leg muscle (Hay et al., 1973).

416 Earlier, it was generally believed that the increase in MFI after slaughter is caused by 417 the weakening of the Z-disk, but electron micrographs (Taylor et al., 1995) of myofibrils used 418 in the MFI assay showed that Z-disks in these myofibrils were intact and that rupture of 419 myofibrils in the MFI assay occurred in the I-band (N2-line) and not at the Z-disk. This 420 suggests that observed post mortem fragmentation of myofibrils is due to degradation of titin 421 and nebulin, which are constituents of the N2-line (Funatsu et al., 1990).

Table 4 near here

\section{Development of tenderness during post mortem storage of breast and leg muscles}

423 Table 4 shows the results of shear force measurements in different muscles with time post 424 mortem. Breast muscles ( $P$. major) were tenderer than leg muscles throughout the 
425 investigation period. In breast muscle, the course of shear force changes is different from that 426 in the investigated leg muscles because of differences in fibre type and different amounts of 427 intramuscular connective tissue. It has previously been shown that in leg muscles (biceps 428 femoris), thickness of perimysium is about two times higher than in breast muscles (Liu et al., 429 1996). Within $24 \mathrm{~h}$ post mortem, breast muscle exhibits its final shear force, however, the 430 maximum shear force is reached at $6 \mathrm{~h}$ post mortem. The leg muscle shear force proceeds 431 much more slowly, but its maximum is reached much earlier at $3 \mathrm{~h}$ post mortem. This 432 indicates a faster rigor development in leg muscle than in breast muscle, but a slower post 433 mortem ageing in the three leg muscles investigated. This is consistent with the results of the 434 SDS-PAGE experiments (Figures 1, 2, 3 and 4) and the results reported in literature (Olson et 435 al., 1976; Hay et al., 1973; Chou et al., 1994).

436 In studies on MFI, it was stated that in breast muscle MFI values reached the plateau at $43724 \mathrm{~h}$ post mortem, whereas the fragmentation process in leg muscles was finished at $48 \mathrm{~h}$ post 438 mortem. Based on the maximum toughness of breast muscle, 95\% of all tenderisation 439 occurred $24 \mathrm{~h}$ post mortem. On the other hand, $81 \%, 89.5 \%$ and $86 \%$ of all tenderisation 440 occurred within $48 \mathrm{~h}$ of slaughter in three leg muscles (biceps femoris, quadriceps femoris, 441 semitendinosus).

Table 5 near here

\section{Cooking loss during post mortem storage}

443 Table 5 shows the results of cooking loss measurements with time post mortem. Cooking loss 444 observed in breast muscle gradually increases after slaughter. In leg muscle, cooking loss first 445 increased quickly, but at $6 \mathrm{~h}$ post mortem, it decreased again. The course of cooking loss 446 changes in leg muscle suggests a relationship with rigor mortis development. During the first $4476 \mathrm{~h}$ after slaughter there is a drop in $\mathrm{pH}$ and an increase of shear force, when rigor mortis 448 occurs, the myofibrillar proteins are approaching the isoelectric point; this leads to a loss of 449 water holding capacity. However, the gradual increase of cooking loss in breast muscle 
450 throughout the investigation period suggests that there is a relationship between cooking loss 451 and post mortem proteolytic breakdown of myofibrillar proteins. It is generally accepted that 452 the cooking loss of meat is inversely correlated with $\mathrm{pH}$, with a range of $5.0-6.5$ being of 456

457

practical importance; any alteration of $\mathrm{pH}$ has a large influence on the water holding capacity of myofibrillar proteins (Pearson and Young, 1989). However, since the $\mathrm{pH}$ decline, as well as other rigor mortis-related factors, does not play a role in post rigor meat, the gradual increase of cooking loss has to be explained by some other mechanism. The degradation of the myofibrillar structure may play a role in the increase in cooking loss.

\section{Relationship between the degradation process of cytoskeletal proteins and meat tenderness, MFI and cooking loss}

461 intensity of different proteins and cleavage products on Western blots were converted to 462 numerical scores as described in the Materials and Methods. Subsequently, the Spearman rank 463 correlation coefficients were calculated for the relationships between these density scores and 464 MFI, cooking loss and shear force measurements. For leg meat, shear force average was 465 calculated for the three muscles tested. This was possible because shear forces were corrected 466 for sample size. Table 6 shows the results of these calculations. Table 6 near here 467 In breast muscle, the degradation of titin as detected on Western blot did not correlate 468 well with meat quality attributes. The trend for of fragment Tc, however, showed very high 469 correlation coefficients with both cooking loss and shear force measurements. The decline of 470 optical density of intact desmin as well as the course of optical density of the Dc fragments 471 showed a high correlation with MFI, cooking loss and shear force, although the correlation of 472 intact desmin with MFI was lower. The Db fragment showed a high correlation with MFI, but 473 lower than the non-significant correlations with cooking loss and shear force measurements. 474 The nebulin decline correlated highly with cooking loss and, to a lesser extent, with shear 
475 force measurements. Nebulin fragment Na was correlated only with MFI. There was only a $4765 \%$ correlation fragment of $\mathrm{Nb}$ with either cooking loss or shear force. The decrease of 477 vinculin showed no significant correlation with any of the traits.

478 In leg muscle tissue, titin fragments $\mathrm{Ta}, \mathrm{Tb}, \mathrm{Td}, \mathrm{Te}$ and $\mathrm{Tf}$ showed significant 479 correlations with MFI, cooking loss and shear force measurements. Only the decrease in the 480 contents of intact titin and the Tc fragment bands showed low correlations. The decrease of 481 intact desmin content and the increase in contents of fragments $\mathrm{Db}$ and $\mathrm{Dc}$ correlated 482 significantly with the course of changes in meat quality traits. The decrease of intact nebulin 483 content and the increase in fragment $\mathrm{Na}$ content correlated significantly with meat quality 484 parameters. The Nb fragment was only significantly correlated with shear force. The decrease 485 in the level of intact vinculin molecules was significantly correlated with MFI and highly 486 correlated with shear force.

\section{Conclusions}

488 It may be stated that the degradation of specific myofibrillar cytoskeletal proteins, as studied 489 in the present work, follows the pattern of post mortem tenderisation and, as such, may be 490 utilised as an indicator of meat ageing. Titin, nebulin and desmin degradations follow a course 491 that is consistent with myofibrillar fragmentation and shear force. However, it has to be taken 492 into account that processes involved in rigor mortis development, such as pH decrease, may 493 interfere with these relationships. More research is needed to identify specific proteolytic 494 fragments of titin, nebulin and desmin, which can serve as specific markers for the estimation 495 of the degree of proteolysis. Once these components are identified, specific probes may be 496 developed to quickly and easily monitor the course of meat ageing. We used Western blot 497 analysis to identify some possible candidate protein fragments that might prove useful for this 498 purpose. However, since Western blotting is a technique that may only be used to identify 499 qualitative variations between different muscle samples it is unsuitable as a method for 
500 measuring quantitatively the course of post mortem proteolytic degradation of cytoskeletal 501 proteins. Immunochemical techniques such as ELISA, however, are of a quantitative nature 502 and future research will thus have to be carried out to develop similar methods, possibly in the 503 form of 'dip-stick' methods or bio-sensors, using the above mentioned specific probes, to 504 monitor meat ageing in-line at the processing plant.

\section{ACKNOWLEDGEMENTS}

506 The authors wish to express their gratitude to H. Goedhart, H.G.M. Reimert, C. van 507 Cruijningen and J.K. Waltmann for their expert technical support. The Dutch Poultry and Egg 508 Board financially supported part of this work.

\section{REFERENCES}

510 BANDMAN, E. \& ZDANIS, D. (1988) An immunological method to assess protein 511 degradation in post-mortem muscle. Meat Science, 22: 1-19.

512 BURNETTE, W.N. (1981) "Western Blotting": Electrophoretic transfer of proteins from 513 sodium dodecyl sulfate -polyacrylamide gels to unmodified nitrocellulose and radiographic 514 detection with antibody and radioiodinated protein. Analytical Biochemistry, 112: 195-203. 515 CHOU, R-G.R., TSENG, T-F., LIN, K-J. \& YANG, J-H. (1994) Post-mortem changes in 516 myofibrillar proteins of breast and leg muscles from broilers, spent hens and Taiwanese 517 country chickens. Journal of the Science of Food Agriculture, 65: 297-302.

518 FRITZ, J.D. \& GREASER, M.L. (1991) Changes in titin and nebulin in postmortem bovine 519 muscle revealed by gel electrophoresis, western blotting and immunofluorescence 520 microscopy. Journal of Food Science, 56: 607-610.

521 FRITZ, J.D., SWARTZ, D.R. \& GREASER, M.L. (1989) Factors affecting polyacrylamide 522 gel electrophoresis and electroblotting of high-molecular weight myofibrillar proteins. 523 Analytical Biochemistry, 180: 205-210. 
524 FUNATSU, T., HIGUCHI, H. \& ISHIWAT, S.I. (1990) Elastic filaments in skeletal muscle 525 revealed by selective removal of thin filaments with plasma gelsolin. Journal of Cell Biology, 526 110: 53-62.

527 GRANZIER, H.L.M. \& WANG, K. (1993) Gel electrophoresis of giant proteins: 528 Solubilization and silver-staining of titin and nebulin from single muscle fiber segments. 529 Electrophoresis, 14: 56-64.

530 HAY, J.D., CURRIE, R.W., WOLFE, F.H. \& SANDERS, E.J. (1973) Effect of post mortem 531 aging on chicken muscle fibrils. Journal of Food Science, 38: 981-986.

532 HWAN, S-F. \& BANDMAN, E. (1989) Studies of desmin and $\alpha$-actinin degradation in 533 bovine semitendinosus muscle. Journal of Food Science, 54: 1426-1430.

534 KIMURA, S., YOSHIDOMI, H. \& MARUYAMA, K. (1984) Proteolytic fragments of 535 connectin cause aggregation of myosin filaments but not of actin filaments. Journal of 536 Biochemistry, 96: 1947-1950.

537 KOOHMARAIE, M., KENNICK, W.H., ELGASIM, E.A. \& ANGLEMIER, A.F. (1984) 538 Effect of postmortem storage on muscle protein degradation: analysis by SDS-polyacrylamide 539 gel electrophoresis. Journal of Food Science, 49: 292-293.

540 LIU, A., NISHIMURA, T. \& TAKAHASHI, K. (1996) Relationship between structural 541 properties of intramuscular connective tissue and toughness of various chicken skeletal 542 muscle. Meat Science, 43: 43-49.

543 LUSBY, M.L., RIDPATH, J.F., PARRISH, F.C. JR. \& ROBSON, R.M. (1983) Effect of 544 postmortem storage on degradation of the myofibrillar protein titin in bovine longissimus 545 muscle. Journal of Food Science, 48: 1787-1795.

546 MARUYAMA, K. (1985). Myofibrillar cytoskeletal proteins of vertebrate striated muscle, in:

547 LAWRIE, R. (Ed) Developments in Meat Science-3, pp. 25-49 (London, Elsevier Applied 548 Science Publishers). 
549 MARUYAMA, K., MATSUBARA, S., NATORI, K., NONOMURA, Y., KIMURA, S., 550 OHASHI, K., MURAKAMI, F., HAND, S. \& EGUCHI, G. (1977) Connectin, an elastic 551 protein of muscle. Journal of Biochemistry, 82: 317-337.

552 OLSON, D.G., PARRISH JR., F.C. \& STROMER, M.H. (1976) Myofibril fragmentation and 553 shear resistance of three bovine muscles during postmortem storage. Journal of Food Science, 554 41: 1036-1041.

555 PATERSON, B.C. \& PARRISH JR., F.C. (1987) SDS-PAGE conditions for detection of titin 556 and nebulin in tender and tough bovine muscle. Journal of Food Science, 52: 509-510. PAXHIA, J.M. \& PARRISH JR., F.C. (1988) Effect of post mortem storage on titin and 558 nebulin in pork and poultry light and dark muscles. Journal of Food Science, 53: 1599-1601. 559 PEARSON, A.M. \& YOUNG, R.B. (1989) Cytoskeletal and Other Proteins of the Myofibrils, 560 in: PEARSON, A.M. \& YOUNG, R.B. (Ed) Muscle and Meat Biochemistry, pp. 131-181 561 (San Diego, Academic Press).

562 PORZIO, M.A. \& PEARSON, A.M. (1977) Improved resolution of myofibrillar proteins with 563 sodium dodecyl sulfate-polyacrylamide gel electrophoresis. Biochimica et Biophisica Acta, 564 490: 27-34.

565 QUALI, A. (1992) Proteolytic and physicochemical mechanism involved in meat texture 566 development. Biochimie, 74: 251-258.

567 ROBSON, R.M. (1995) Myofibrillar and cytoskeletal structures and proteins in mature 568 skeletal muscle cells, in: QUALI, A., DEMEYER, D.I. \& SMULDERS, F.J. (Eds) Expression 569 of Tissue Proteinases and Regulation of Protein Degradation as Related to Meat Quality, pp. 570 267-281 (Utrecht, ECCEAMST).

571 SAMEJIMA, K. \& WOLFE, F.H. (1976) Degradation of myofibrillar protein components 572 during post-mortem ageing of chicken muscle. Journal of Food Science, 41: 250-254. 
573 SCHREURS, F.J.G. (1991) An immunological method to assess proteolytic breakdown of 574 desmin, a structural myofibrillar protein, in broiler breast meat. Proceedings of 10th 575 European Symposium on the Quality of Poultry Meat, Doorwerth pp. 69-76.

576 STUDIER, F.W. (1973) Analysis of bacteriophage T7 early RNA's and protein on slab gels. 577 Journal of Molecular Biology, 79: 237-248.

578 TANABE, R., NAKAI, H. \& TAKAHASHI, K. (1992) Post mortem changes in skeletal 579 muscle connectin. Proceedings of 38th International Congress of Meat Science and 580 Technology, Vol 3,Clermont-Ferrand pp. 427-432.

581 TAYLOR, R.G., GEESINK, G.H., THOMPSON, V.F., KOOHMARAIE M. \& GOLL, D.E. 582 (1995) Is Z-disk degradation responsible for postmortem tenderization? Journal of Animal 583 Science, 73: 1351-1367.

584 TOMASZEWSKA-GRAS, J., KIJOWSKI, J. \& SCHREURS, F. (1999) Titin and nebulin 585 degradation in relation to myofibrillar fragmentation index and tenderness in broiler meat. 586 Proceedings of 14th European Symposium on the Quality of Poultry Meat, Bologna pp. 143587150.

588 TOMASZEWSKA-GRAS, J., SCHREURS, F. \& KIJOWSKI, J (2002) Quantitative 589 determination of titin and nebulin in poultry meat by SDS-PAGE with an internal standard. 590 Meat Science, 62: 61-66

591 WANG, K. (1982) Purification of titin and nebulin. Methods Enzymology, 85: 264-274.

592 WANG, K, MCCLURE, J. \& TU, A. (1979) Titin: major myofibrillar components of striated 593 muscle. Proceedings of National Academy of Science, U.S.A., 72: 3698-3702.

594 YATES, L.D., DUTSON, T.R., CALDWELL, J. \& CARPENTER, Z.L. (1983) Effect of 595 temperature and $\mathrm{pH}$ on the post-mortem degradation of myofibrillar proteins. Meat Science, 596 9: 157-162. 
3597 YOUNG, O.A., GRAAFHUIS, A.E. \& DAVEY, L. (1980) Post mortem changes in 5 598 cytoskeletal muscle. Meat Science, 5: 41-55. 
Table 1. Changes in amounts of titin and nebulin determined by $7.5 \%$ SDS-PAGE, quantitative method with internal standards (breast, pectoralis major; leg, biceps femoris)

\begin{tabular}{ccccc}
\hline \multirow{2}{*}{$\begin{array}{c}\text { Time post } \\
\begin{array}{c}\text { mortem } \\
(\mathrm{h})\end{array}\end{array}$} & \multicolumn{2}{c}{$\begin{array}{c}\text { Titin content as percentage of } \\
\text { total protein content }\end{array}$} & \multicolumn{2}{c}{$\begin{array}{c}\text { Nebulin content as percentage } \\
\text { of total protein content }\end{array}$} \\
\cline { 2 - 5 } & $\begin{array}{c}\text { Breast } \\
\mathrm{n}=13\end{array}$ & $\begin{array}{c}\text { Leg } \\
\mathrm{n}=13\end{array}$ & $\begin{array}{c}\text { Breast } \\
\mathrm{n}=13\end{array}$ & $\begin{array}{c}\text { Leg } \\
\mathrm{n}=13\end{array}$ \\
\hline 0 & $5.7 \pm 0.49^{\mathrm{a}}$ & $5.8 \pm 0.84^{\mathrm{a}}$ & $1.6 \pm 0.14^{\mathrm{a}}$ & $1.6 \pm 0.33^{\mathrm{a}}$ \\
1 & $5.9 \pm 0.59^{\mathrm{a}}$ & $5.8 \pm 0.56^{\mathrm{ab}}$ & $1.7 \pm 0.17^{\mathrm{a}}$ & $1.4 \pm 0.30^{\mathrm{a}}$ \\
3 & $5.8 \pm 0.51^{\mathrm{a}}$ & $5.5 \pm 0.63^{\mathrm{ab}}$ & $1.7 \pm 0.16^{\mathrm{a}}$ & $1.3 \pm 0.29^{\mathrm{a}}$ \\
6 & $5.7 \pm 0.77^{\mathrm{a}}$ & $5.6 \pm 0.48^{\mathrm{ab}}$ & $1.6 \pm 0.24^{\mathrm{a}}$ & $1.4 \pm 0.40^{\mathrm{a}}$ \\
24 & $4.6 \pm 0.62^{\mathrm{b}}$ & $5.5 \pm 0.48^{\mathrm{ab}}$ & $1.4 \pm 0.15^{\mathrm{b}}$ & $1.5 \pm 0.38^{\mathrm{b}}$ \\
48 & $4.4 \pm 0.32^{\mathrm{b}}$ & $5.1 \pm 0.51^{\mathrm{b}}$ & $1.3 \pm 0.19^{\mathrm{b}}$ & $1.1 \pm 0.33^{\mathrm{b}}$ \\
72 & $4.6 \pm 0.39^{\mathrm{b}}$ & $4.0 \pm 0.56^{\mathrm{c}}$ & $1.2 \pm 0.15^{\mathrm{b}}$ & $0.8 \pm 0.23^{\mathrm{c}}$ \\
120 & $4.6 \pm 0.49^{\mathrm{b}}$ & $3.6 \pm 0.66^{\mathrm{c}}$ & $1.1 \pm 0.23^{\mathrm{c}}$ & $0.7 \pm 0.22^{\mathrm{c}}$ \\
168 & $4.3 \pm 0.44^{\mathrm{b}}$ & $3.5 \pm 0.56^{\mathrm{c}}$ & $0.9 \pm 0.21^{\mathrm{c}}$ & $0.6 \pm 0.16^{\mathrm{c}}$ \\
\hline
\end{tabular}

599 Group averages and standard deviations are shown.

600 Group averages not sharing a common superscript differ significantly within columns at $P$ $601 \leq 0.05$.

$602 \mathrm{n}=$ number of samples from the same 13 carcases. 
603 Table 2. Relative optical densities of bands on Western blots (number of blots $n=3$ ) in chicken breast (P. major) and leg (biceps femoris) muscles

Time post mortem $(\mathrm{h})$

\begin{tabular}{|c|c|c|c|c|c|c|c|c|c|c|c|}
\hline & Fragment & Mw & 0 & 1 & 3 & 6 & 24 & 48 & 72 & 120 & 168 \\
\hline \multirow{14}{*}{$\begin{array}{c}\text { Breast } \\
(\text { P. major })\end{array}$} & Titin & 2800 & ++ & ++ & ++ & ++ & ++ & ++ & ++ & ++ & + \\
\hline & $\mathrm{Ta}$ & 1700 & + & ++ & ++ & ++ & +++ & +++ & +++ & ++ & ++ \\
\hline & $\mathrm{Tb}$ & 1400 & - & - & - & - & - & - & \pm & ++ & ++ \\
\hline & $\mathrm{Tc}$ & 1100 & + & ++ & ++ & ++ & + & \pm & - & - & - \\
\hline & $\mathrm{Td}$ & 900 & + & + & ++ & ++ & ++ & +++ & ++ & ++ & + \\
\hline & $\mathrm{Te}$ & 700 & - & \pm & + & + & ++ & +++ & ++ & +++ & + \\
\hline & Desmin & 53 & +++ & +++ & +++ & +++ & ++ & + & \pm & - & - \\
\hline & $\mathrm{Da}$ & 47 & - & - & \pm & + & ++ & ++ & + & \pm & + \\
\hline & $\mathrm{Db}$ & 40 & - & - & - & \pm & + & + & ++ & + & + \\
\hline & Dc & $30-37$ & - & - & - & - & \pm & \pm & + & + & + \\
\hline & Nebulin & 800 & ++ & ++ & ++ & + & + & - & - & - & - \\
\hline & $\mathrm{Na}$ & 500 & - & - & - & \pm & \pm & + & ++ & \pm & \pm \\
\hline & $\mathrm{Nb}$ & 400 & - & - & - & - & - & - & \pm & + & + \\
\hline & Vinculin & 126 & \pm & + & + & + & + & + & \pm & - & - \\
\hline \multirow{15}{*}{$\begin{array}{c}\text { Leg } \\
\text { (biceps } \\
\text { femoris) }\end{array}$} & Titin & 2800 & + & ++ & ++ & ++ & + & + & + & + & \pm \\
\hline & $\mathrm{Ta}$ & 1700 & ++ & ++ & ++ & ++ & ++ & + & + & + & + \\
\hline & $\mathrm{Tb}$ & 1400 & - & - & - & - & \pm & + & + & + & + \\
\hline & $\mathrm{Tc}$ & 1100 & \pm & \pm & \pm & \pm & \pm & + & + & + & \pm \\
\hline & $\mathrm{Td}$ & 900 & - & \pm & \pm & \pm & + & +++ & +++ & +++ & +++ \\
\hline & $\mathrm{Te}$ & 700 & \pm & + & + & + & + & ++ & ++ & ++ & ++ \\
\hline & $\mathrm{Tf}$ & & - & - & - & \pm & \pm & + & + & + & + \\
\hline & Desmin & 53 & +++ & +++ & +++ & +++ & +++ & ++ & + & \pm & \pm \\
\hline & $\mathrm{Da}$ & 47 & & \pm & \pm & \pm & \pm & + & + & + & \pm \\
\hline & $\mathrm{Db}$ & 40 & - & - & - & - & - & + & + & + & \pm \\
\hline & Dc & $30-37$ & - & - & - & - & - & \pm & + & + & + \\
\hline & Nebulin & 800 & +++ & ++ & ++ & + & + & - & - & - & - \\
\hline & $\mathrm{Na}$ & 500 & - & - & - & - & \pm & + & \pm & + & \pm \\
\hline & $\mathrm{Nb}$ & 400 & - & - & - & - & - & - & \pm & \pm & \pm \\
\hline & Vinculin & 126 & ++ & ++ & ++ & ++ & ++ & ++ & + & + & \pm \\
\hline
\end{tabular}

E-mail: br.poultsci@bbsrc.ac.uk URL: http://mc.manuscriptcentral.com/cbps 
604 Table 3. Changes in myofibrillar fragmentation index (MFI) with time post mortem in breast 605

\begin{tabular}{ccc} 
(P. major) and leg muscles (considered as a whole) \\
\hline \multirow{2}{*}{$\begin{array}{c}\text { Time post mortem } \\
(\mathrm{h})\end{array}$} & \multicolumn{2}{c}{ MFI } \\
\cline { 2 - 3 }$(\mathrm{n}=18)$ & $\begin{array}{c}\text { Leg } \\
(\mathrm{n}=18)\end{array}$ \\
\hline 0 & $30.0 \pm 7.9^{\mathrm{a}}$ & $18.0 \pm 3.7^{\mathrm{a}}$ \\
1 & $35.3 \pm 9.0^{\mathrm{b}}$ & $20.5 \pm 3.6^{\mathrm{a}}$ \\
3 & $40.6 \pm 10.7^{\mathrm{c}}$ & $23.3 \pm 3.5^{\mathrm{b}}$ \\
6 & $52.6 \pm 9.1^{\mathrm{d}}$ & $25.1 \pm 3.3^{\mathrm{bc}}$ \\
24 & $62.8 \pm 6.3^{\mathrm{e}}$ & $26.2 \pm 4.5^{\mathrm{cd}}$ \\
48 & $66.3 \pm 4.8^{\mathrm{e}}$ & $30.7 \pm 5.7^{\mathrm{e}}$ \\
72 & $66.0 \pm 5.0^{\mathrm{e}}$ & $30.1 \pm 2.3^{\mathrm{e}}$ \\
120 & $65.6 \pm 6.8^{\mathrm{e}}$ & $28.7 \pm 3.8^{\mathrm{de}}$ \\
168 & $62.9 \pm 9.4^{\mathrm{e}}$ & $33.5 \pm 4.7^{\mathrm{f}}$ \\
\hline
\end{tabular}

606 Group averages and standard deviations are shown.

607 Group averages not sharing a common superscript differ significantly within columns at $P$ $608 \leq 0.05$.

$609 \mathrm{n}=$ number of muscle samples, measurements in 18 separate muscle samples, each made in 610 duplicate. 
611 Table 4. Shear force in P. major, biceps femoris, quadriceps femoris and semitendinosus 612 chicken muscles with time post mortem

\begin{tabular}{ccccc}
\hline $\begin{array}{c}\text { Time } \\
\text { post } \\
\text { mortem } \\
(\mathrm{h})\end{array}$ & $\begin{array}{c}\text { Breast } \\
\text { (pectoralis } \\
\text { major }) \\
(\mathrm{n}=24)\end{array}$ & $\begin{array}{c}\text { Leg } \\
\text { (biceps femoris }) \\
(\mathrm{n}=24)\end{array}$ & $\begin{array}{c}\text { Shear force }\left(\mathrm{N} / \mathrm{cm}^{2}\right) \\
(\text { quadriceps } \\
\text { femoris })(\mathrm{n}=24)\end{array}$ & $\begin{array}{c}\text { Leg } \\
\left(\begin{array}{c}\text { semitendinosus }) \\
(\mathrm{n}=24)\end{array}\right.\end{array}$ \\
\hline 0 & $35.8 \pm 5.3^{\mathrm{c}}$ & $78.5 \pm 11.1^{\mathrm{c}}$ & $116.9 \pm 18.0^{\mathrm{a}}$ & $83.0 \pm 19.0^{\mathrm{b}}$ \\
3 & $46.6 \pm 9.0^{\mathrm{b}}$ & $104.5 \pm 18.9^{\mathrm{a}}$ & $92.6 \pm 9.8^{\mathrm{b}}$ & $91.9 \pm 19.4^{\mathrm{a}}$ \\
6 & $93.3 \pm 23.2^{\mathrm{a}}$ & $89.5 \pm 13.5^{\mathrm{b}}$ & $95.7 \pm 14.5^{\mathrm{b}}$ & $71.8 \pm 19.2^{\mathrm{c}}$ \\
24 & $17.9 \pm 6.8^{\mathrm{d}}$ & $45.4 \pm 6.8^{\mathrm{d}}$ & $56.9 \pm 12.1^{\mathrm{c}}$ & $41.4 \pm 8.6^{\mathrm{d}}$ \\
48 & $15.8 \pm 3.8^{\mathrm{d}}$ & $44.3 \pm 6.1^{\mathrm{d}}$ & $39.1 \pm 6.7^{\mathrm{d}}$ & $34.7 \pm 6.7^{\mathrm{de}}$ \\
72 & $16.3 \pm 5.3^{\mathrm{d}}$ & $37.5 \pm 5.7^{\mathrm{e}}$ & $35.4 \pm 6.0^{\mathrm{de}}$ & $28.5 \pm 6.0^{\mathrm{ef}}$ \\
120 & $15.6 \pm 3.0^{\mathrm{d}}$ & $34.3 \pm 6.7^{\mathrm{ef}}$ & $32.7 \pm 6.4^{\mathrm{de}}$ & $27.2 \pm 3.8^{\mathrm{ef}}$ \\
168 & $14.3 \pm 3.3^{\mathrm{d}}$ & $30.0 \pm 6.1^{\mathrm{f}}$ & $29.9 \pm 7.1^{\mathrm{e}}$ & $24.6 \pm 5.5^{\mathrm{f}}$ \\
\hline
\end{tabular}

613 Group averages and standard deviations are shown

614 Group averages not sharing a common superscript differ significantly within columns at $P$ $615 \leq 0.05$.

$616 \mathrm{n}=$ number of muscle samples, measurements in 24 separate muscle samples, each made in 617 duplicate. 
618 Table 5. Changes in $\mathrm{pH}$ and cooking loss of breast and leg muscles during post mortem storage 619

\begin{tabular}{|c|c|c|c|c|}
\hline \multirow{2}{*}{$\begin{array}{c}\text { Time } \\
\text { post } \\
\text { mortem } \\
\text { (h) }\end{array}$} & \multicolumn{2}{|c|}{$\mathrm{pH}$} & \multicolumn{2}{|c|}{ Cooking loss $(\%)$} \\
\hline & $\begin{array}{l}\text { Breast } \\
\mathrm{n}=24\end{array}$ & $\begin{array}{c}\text { Leg } \\
\mathrm{n}=24\end{array}$ & $\begin{array}{l}\text { Breast } \\
\mathrm{n}=24\end{array}$ & $\begin{array}{c}\text { Leg } \\
n=24\end{array}$ \\
\hline 0 & $6.3 \pm 0.10^{\mathrm{a}}$ & $6.5 \pm 0.16^{\mathrm{a}}$ & $4.8 \pm 0.96^{\mathrm{a}}$ & $8.7 \pm 0.88^{\mathrm{c}}$ \\
\hline 3 & $6.0 \pm 0.25^{\mathrm{b}}$ & $6.2 \pm 0.24^{\mathrm{bc}}$ & $6.2 \pm 1.14^{\mathrm{b}}$ & $9.8 \pm 1.73^{\mathrm{d}}$ \\
\hline 6 & $5.6 \pm 0.25^{\mathrm{c}}$ & $6.1 \pm 0.13^{\mathrm{c}}$ & $6.9 \pm 0.81^{b c}$ & $11.5 \pm 1.92^{\mathrm{e}}$ \\
\hline 24 & $5.4 \pm 0.13^{\mathrm{d}}$ & $6.1 \pm 0.25^{\mathrm{c}}$ & $7.2 \pm 0.96^{\mathrm{c}}$ & $8.2 \pm 1.31^{\mathrm{bc}}$ \\
\hline 48 & $5.6 \pm 0.19^{\mathrm{cd}}$ & $6.1 \pm 0.08^{\mathrm{c}}$ & $8.8 \pm 1.60^{\mathrm{d}}$ & $7.4 \pm 1.17^{\mathrm{ab}}$ \\
\hline 72 & $5.5 \pm 0.15^{\mathrm{cd}}$ & $6.2 \pm 0.18^{\mathrm{bc}}$ & $8.8 \pm 1.57^{\mathrm{d}}$ & $6.9 \pm 1.36^{\mathrm{a}}$ \\
\hline 120 & $5.6 \pm 0.14^{\mathrm{c}}$ & $6.2 \pm 0.18^{b c}$ & $9.5 \pm 2.02^{\mathrm{d}}$ & $7.9 \pm 1.52^{\mathrm{bc}}$ \\
\hline 168 & $5.8 \pm 0.19^{e}$ & $6.3 \pm 0.10^{\mathrm{ab}}$ & $9.3 \pm 1.76^{\mathrm{d}}$ & $8.0 \pm 1.47^{\mathrm{bc}}$ \\
\hline
\end{tabular}

620 Group averages and standard deviations are shown.

621 Group averages not sharing a common superscript differ significantly within columns at $P$ $622 \leq 0.05$.

$623 \mathrm{n}=$ number of muscle samples, measurements in 24 separate muscle samples, each made in 624 duplicate. 
625 Table 6. Correlation coefficients determined for dependencies between changes in cytoskeletal 626 proteins and qualitative parameters of poultry meat stored for $7 \mathrm{~d}$ at $4{ }^{\circ} \mathrm{C}$

\begin{tabular}{|c|c|c|c|c|c|c|c|c|c|}
\hline \multicolumn{5}{|c|}{ Breast meat (P. major) } & \multicolumn{5}{|c|}{ Leg meat } \\
\hline & & MFI & $\begin{array}{c}\text { Cooking } \\
\text { loss }\end{array}$ & $\begin{array}{l}\text { Shear } \\
\text { force }\end{array}$ & & & MFI & $\begin{array}{c}\text { Cooking } \\
\text { loss }\end{array}$ & $\begin{array}{l}\text { Shear } \\
\text { force }\end{array}$ \\
\hline \multirow{2}{*}{ 㿝罗 } & Titin & $-0.910 * *$ & $-0.861 * *$ & $0.909 * *$ & \multirow{2}{*}{ 岳峲 } & Titin & $-0.790 *$ & 0.581 & $0.880 * *$ \\
\hline & Nebulin & $-0.770 *$ & $-0.868 * *$ & $0.780 *$ & & Nebulin & $-0.877 * *$ & 0.577 & $0.922 * *$ \\
\hline \multirow{15}{*}{ 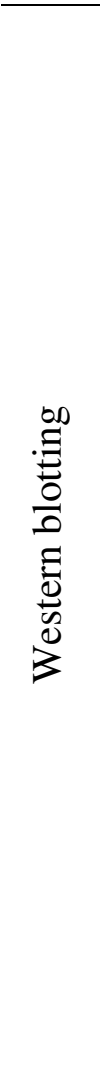 } & Titin & -0.137 & -0.415 & 0.577 & \multirow{15}{*}{ 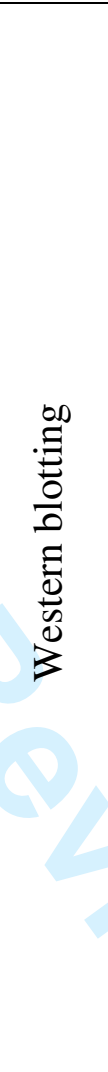 } & Titin & $-0.671 *$ & 0.619 & $0.770 *$ \\
\hline & $\mathrm{Ta}$ & 0.597 & 0.177 & 0.013 & & $\mathrm{Ta}$ & $-0.866 * *$ & $0.873 * *$ & $0.873 * *$ \\
\hline & $\mathrm{Tb}$ & 0.508 & $0.830 *$ & $-0.784^{*}$ & & $\mathrm{~Tb}$ & $-0.913 * *$ & $-0.913 * *$ & $-0.913 * *$ \\
\hline & $\mathrm{Tc}$ & $-0.728 *$ & $-0.845 * *$ & $0.914 * *$ & & $\mathrm{Tc}$ & 0.548 & $-0.845 * *$ & -0.507 \\
\hline & $\mathrm{Td}$ & $0.671 *$ & 0.180 & 0.069 & & $\mathrm{Td}$ & $0.940 * *$ & $-0.856 * *$ & $-0.894 * *$ \\
\hline & $\mathrm{Te}$ & $0.898 * *$ & $0.708 *$ & -0.519 & & $\mathrm{Te}$ & $0.913 * *$ & $-0.809 *$ & $-0.861 * *$ \\
\hline & Desmin & $-0.796 *$ & $-0.963 * *$ & $-0.945 * *$ & & $\mathrm{Tf}$ & $0.935^{* *}$ & $-0.823^{*}$ & $-0.926 * *$ \\
\hline & $\mathrm{Da}$ & $0.713 *$ & 0.317 & -0.210 & & Desmin & $-0.817 * *$ & $0.728^{*}$ & $0.932 * *$ \\
\hline & $\mathrm{Db}$ & $0.896^{* *}$ & $0.777 *$ & -0.664 & & $\mathrm{Da}$ & $0.671^{*}$ & $-0.782 *$ & -0.574 \\
\hline & Dc & $0.802 * *$ & $0.919 * *$ & $-0.882 * *$ & & $\mathrm{Db}$ & $0.783 *$ & $-0.913 * *$ & $-0.756^{*}$ \\
\hline & Nebulin & $-0.935 * *$ & $-0.931 * *$ & $0.823^{*}$ & & Dc & $0.820 * *$ & $-0.809 *$ & $-0.913 * *$ \\
\hline & $\mathrm{Na}$ & $0.922 * *$ & 0.617 & -0.447 & & Nebulin & $-0.949 * *$ & $0.805^{*}$ & $0.907 * *$ \\
\hline & $\mathrm{Nb}$ & 0.508 & $0.830 *$ & -0.784 & & $\mathrm{Na}$ & $0.802 * *$ & $-0.819 *$ & $-0.756^{*}$ \\
\hline & \multirow[t]{2}{*}{ Vinculin } & -0.173 & -0.384 & 0.546 & & $\mathrm{Nb}$ & 0.639 & -0.620 & $-0.845 * *$ \\
\hline & & & & & & Vinculin & $-0.677 *$ & 0.550 & $0.866 * *$ \\
\hline
\end{tabular}

627 Correlations significant at $* P \leq 0.05$ level (2-tailed), $* * P \leq 0.01$ level (2-tailed). 
Figure 1. SDS-PAGE of 3.2\% gel of chicken muscles (breast and leg) at 0, 1, 3, 6, 24, 48, 72, 632120 and $168 \mathrm{~h}$ post mortem and stored at the temperature $4^{\circ} \mathrm{C}$.

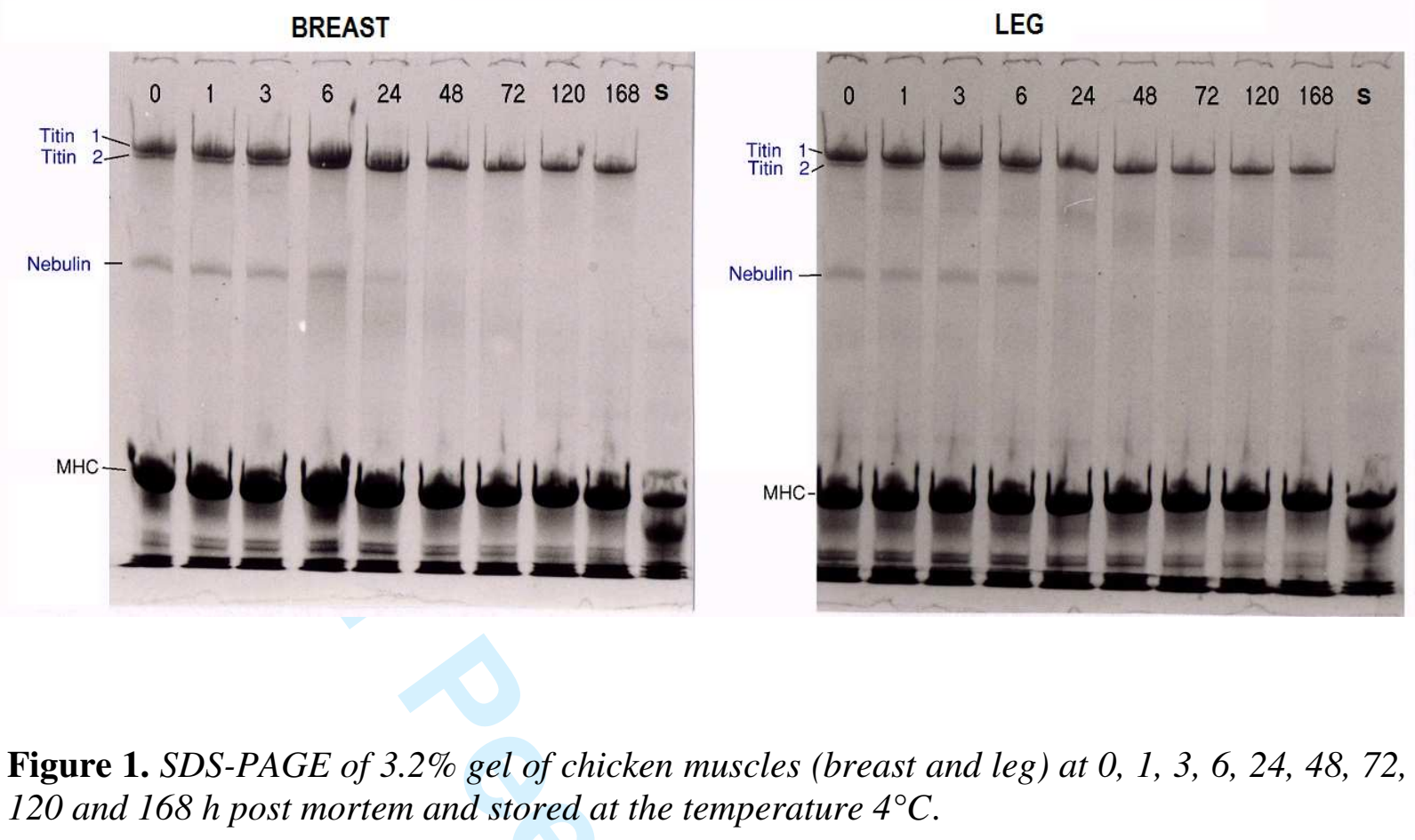



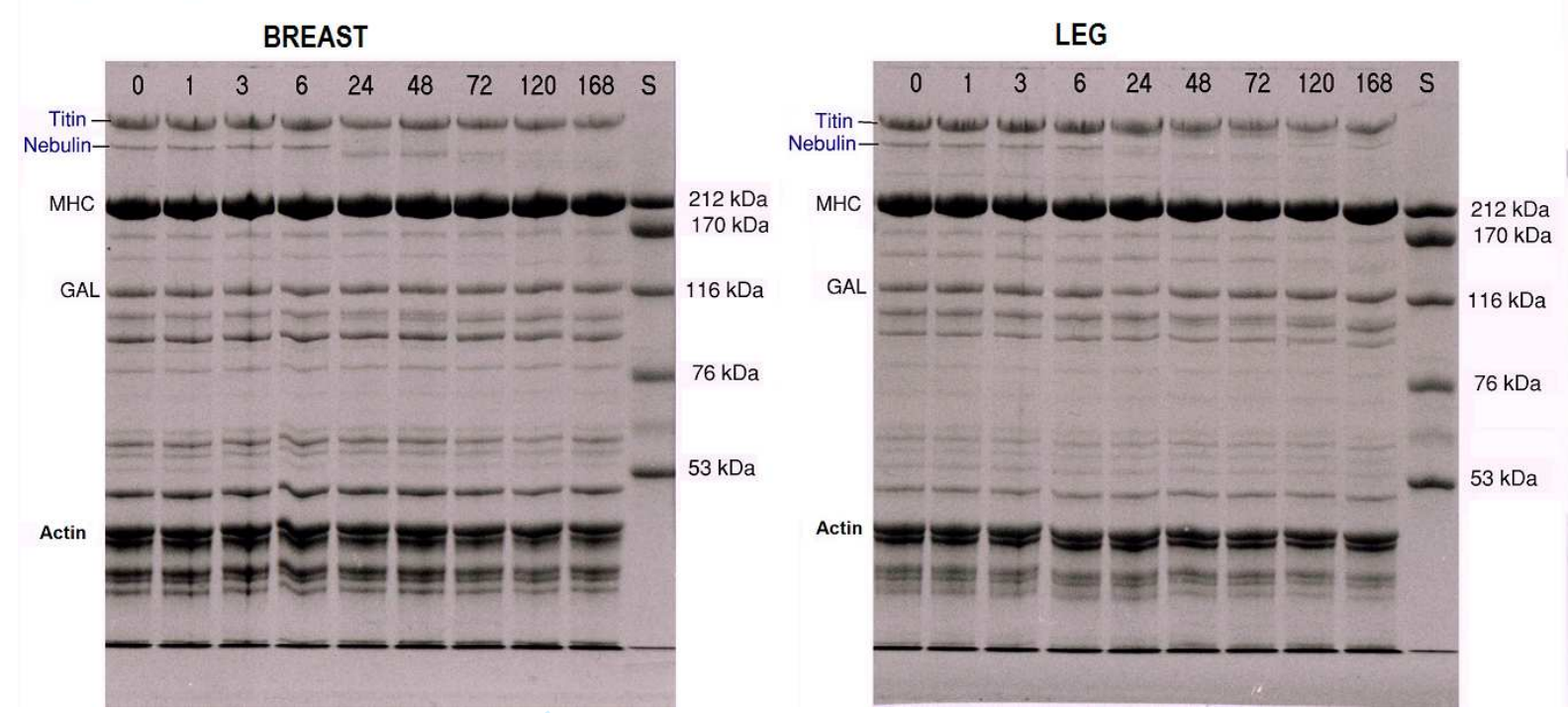

Figure 2. SDS-PAGE of 7.5\% gel of chicken muscles samples (breast and leg) at 0, 1, 3, 6, $63524,48,72,120$ and $168 \mathrm{~h}$ post mortem when stored at $4^{\circ} \mathrm{C}$ with internal standard $(G A L-\beta$ 636 galactosidase) $S$ - marker proteins: myosin $(212 \mathrm{kDa}), \alpha$-macroglobulin $(170 \mathrm{kDa}), \beta$ 637 galactosidaze (116 kDa), transferrin (76 kDa) and glutamic dehydrogenase (53 kDa). 

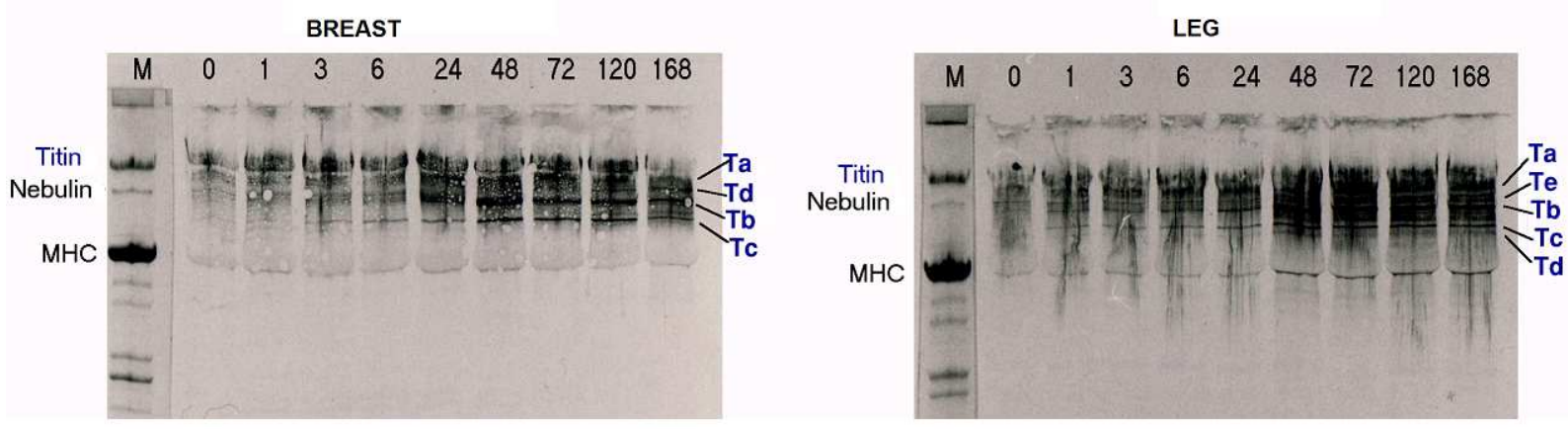

638

639 Figure 3. Western blotting of titin at 0, 1, 3, 6, 24, 48, 72, 120 and 168 host mortem using 640 polyclonal antibody to titin in breast and leg chicken muscles. $M$-SDS-PAGE of sample at 641 '0' time. 
642

\section{3} 644 645 646 647
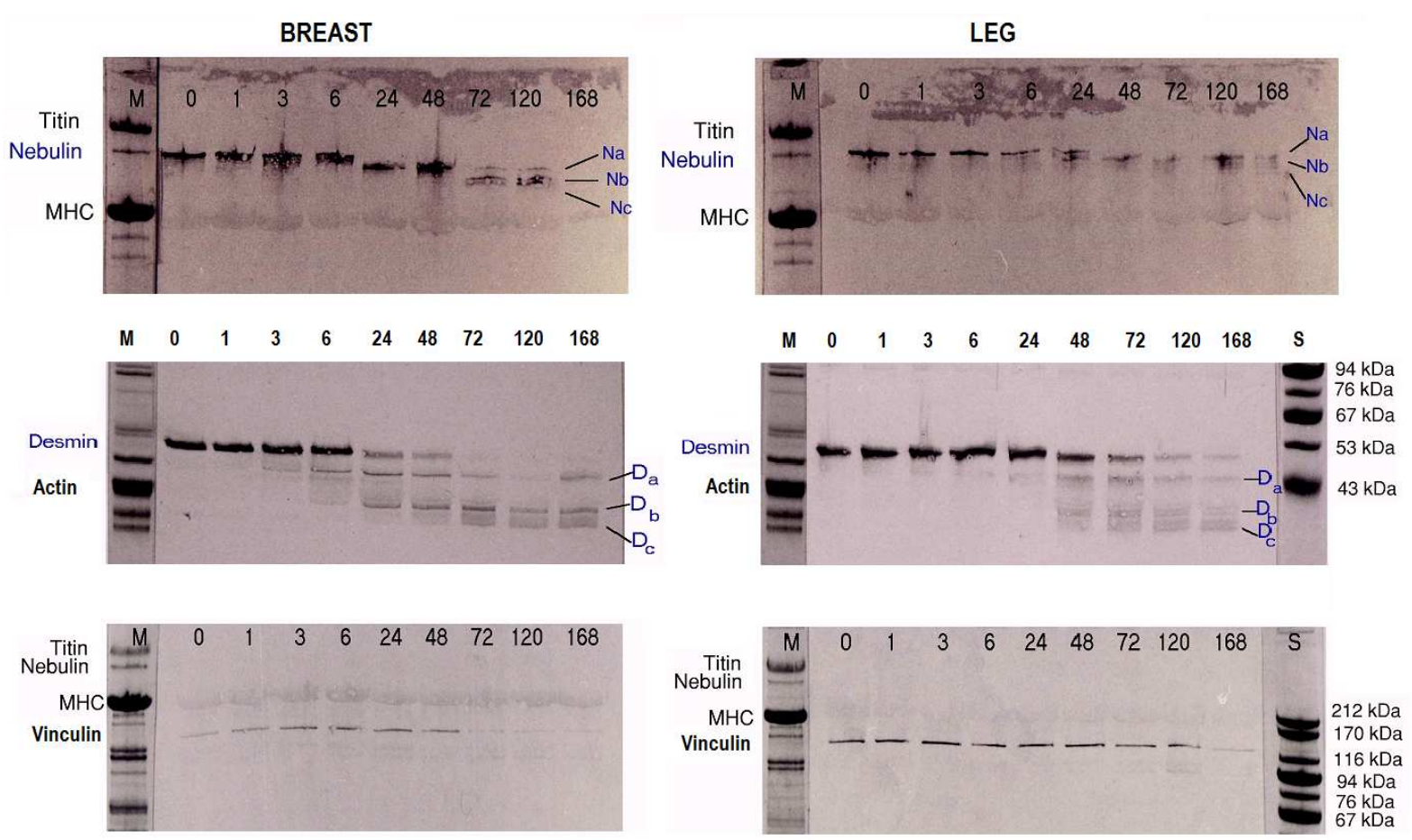

Figure 4. Western blotting of three cytoskeletal proteins at 0, 1, 3, 6, 24, 48, 72, 120 and 168 $h$ post mortem using polyclonal antibody to desmin and monoclonal antibody to nebulin and vinculin in breast and leg chicken muscles. $M-S D S$ - PAGE of sample at 'O' time. S - SDSPAGE of sample with molecular weight marker proteins. 